\title{
The Case-Based Learning Approach to Operating System Installation Subject Course
}

\author{
Siscka Elvyanti ${ }^{1}$, Aziz Mujtahid ${ }^{2}$ \\ Universitas Pendidikan Indonesia \\ Jalan Setiabudi 207, Bandung 40154, Indonesia \\ 1siscka_elvyanti@yahoo.com, ${ }^{2}$ mujtahida@yahoo.co.id
}

\begin{abstract}
Teaching operating system installation subject course is a way for students to learn some aspects of computer and networking. Case-based learning is one of the main successful students centered pedagogies broadly used in computer and networking subject course. In this paper, a worked case-based learning is presented as an approach, a practical case-based system operation installation subject course supported by Software Oracle VmVirtualbox. The results corroborated the effectiveness of the case-based approach in practical system operation installation teaching learning.
\end{abstract}

Index Terms - operating system, case-based learning, teaching learning, computer.

\section{Introduction}

In the traditional approach, a course is first taught through lecturing and perhaps tutoring. Students are then expected to solve problems or do projects, sometimes in laboratories, based on the subjects already taught [1]. Casebased learning is a pedagogical method that uses case studies as active learning tools [2]. Case-based learning integrates definition-based learning, solution-based learning, and problem based learning [3]. Kjaerulff, et al. said that case-based learning model considers an iterative situation, problem solving, problem orientation, and innovation. A case study is composed of a strategy that uses a problem of real life as a vehicle for discussion and creative thinking around the subject matter.

Case-based learning allows students (1) to understand a concept as what they learned through the cases; (2) to develop a collaborative, team-based approach to their education from the face to face learning situation; and (3) to understand the approach as how their learning of the cases [4]. Outcomes from this study can therefore improve the students' concepts, approaches, and collaboration.

Operating system installation is a subject matter that requires practical learning so that students can understand and apply the installation process correctly. This case study examines how a case-based learning approach is used in learning the operating system installation. Furthermore, this study emphasizes the support of computer software as a learning tool. In such classroom learning, students are typically working with him/herself and developing the knowledge by discussion. In this study, the implementation of case-based learning is intended to allow the teacher to provide assistance to students who may not meet the learning-centered self-improvement with a focus on developing interactive and collaborative approaches expected to overcome independent student learning difficulties.

This case study aims to explore the effectiveness of case-based learning as an educational method in system operation installation learning process. This investigation's goal was to address two research questions:

1. Is there a significant difference between the performance on content assessments of students who use the case-based learning and those who do not use the case-based learning?

2. Does the case-based learning effectively address the better learning process?

\section{Methods}

This study is typically performed in two groups randomly assigned as a case-based and non-case-based group. The first group - case-based group - is typically performed in small teams. Every team consisted of two to three students, in which information was shared between the team members. The case-based group consisted of 43 students (12 females, 31 males) with 37 completing both pre- and post-tests, 2 completing the pre-test only.

The second group - non-case-based group - consisted of 49 students (10 females, 29 males) with 39 completing both pre- and post-tests. In this group, the student performed in the individual independent. This kind of study design was expected to be successful to address the research question. For example, how to apply skills such as testing and configuring at operating system installation studied in the classroom with very limited perspective of the actual problems faced in real situations. This study examined this topic by two group design with different treatments.

Beside pre- and post-test as an assessment of student knowledge, this study made an evaluation of student attitudes by conducting an attitudinal questionnaire-based survey with closed questions during the classroom. An attitudinal questionnaire was devised to have questions that provide information on three attitude scales: learning experience, knowledge, and collaboration. This was then used as a pre- and post-measure of attitude towards casebased learning and non-case-based learning.

The pre- and post-test were designed to access comprehension of content that is focused on operating system installation. The tests were scored out of 100 points and were composed of multiple choice and short answer questions. The paper contains 35 questions. The pre-test have been done 2 days before starting the operating system 
installation class. The topic of operating system installation was covered in three class sessions, in which each class session was $80 \mathrm{~min}$. The post-test was administrated after all class sessions have been done. Students then completed the post-test and attitudinal questionnaire.

An attitudinal questionnaire was then used as a pre- and post-measure of attitude toward case-based learning to noncase-based learning. Students completed the questionnaire at the same time as they completed the post-test of knowledge. The attitude scales used Likert items. The first attitude scale is learning experience scale that consists of four questions and it is interpreted as measuring a change of positive attitude in the learning process. The second one is knowledge scale that consists of three questions and it is interpreted as much knowledge that can be gained from case-based learning programs as from classroom activity. And the third one is collaboration scale that consists of three items with focusing on case-based earning allows students to work together, and collaborate in developing their knowledge.

\section{Evaluation of student knowledge}

A multiple choice question was used on pre- and posttest to assess students' knowledge. Students' responses to multiple choice questions were tabulated and the chi square test was used to determine if a relationship existed between student performance and the assigned group (Table 1).

A normalized learning gain was used to compare learning outcomes across the different groups. The gain was calculated for each student who completed both pre-and post-test and averaged for each group [5].

\section{Evaluation of student attitude}

An attitudinal questionnaire measured students' perceptions of the learning experience, knowledge, and level of collaboration with other students (Table 2). The attitudinal questionnaire scales consisted of Likert scales. Each item on a scale has five points scored from +2 (strongly agree), +1 (agree), through 0 (undecided), -1 (disagree) to -2 (strongly disagree) and open ended format. The students' responses were analyzed and common themes were gleaned to generate a categorization scheme in Table 2. Individual student comments were then scored based on this scheme. For example, a student's response "I now know of some other approaches that might work better to solve the operating system problem" was scored once in the learning experience category and one in the knowledge category. Thus, a student's response could be scored in one or more categories.

\section{Results and Discussion}

\section{Student Knowledge}

The results of the pre- and post-test of knowledge are presented in Table 1.A substantial increase in knowledge was seen in the post-test scores, when compared with the pre-test scores. To determine the effectiveness of the approach, the group who learned using case-based learning was compared with non-based learning groups. Based on a hypothesis, students in case-based learning group would achieve a higher average normalized learning gain $(\mathrm{g})$ when compared with students in group non-case-based learning. Students in both groups demonstrated similar scores on the pre-test, suggesting that the students had similar baseline knowledge of operating system installation. Based on analyzing data, students in case-based group significantly shows a higher average normalized $(\mathrm{g}=0.51$, significance $=$ $0.05)$ when compared with students in non-case-based group $(\mathrm{g}=0.13$, significance $=0.05)$ with the size effect of $\mathrm{d}=$ 0.97 . These results suggest that the students in case-based group achieved significantly higher learning gains relative to the non-case-based group.

One group of the case study's design was to help students enhance their conception in the operating system. It was hypothesized that students in base-cased group would have a significantly higher rate of learning enhancement when compared with students in the non-case-based group. The proportion of students who answered to determine which student maintained the understanding after the classes. In the case-based group, 86.5\% (32/37) of students answered the post-test question correctly when compared with $82.1 \%$ (32/39) of students in the non-case-based group (Table 1). A chi-square test of independence was performed to examine the relation between the performances on the post-test questions and the assigned group.

In addition to students' responses on the post-test attitude, a higher-order thinking question was included on both the pre- and post-test as one measure of students' data analysis skills. The relation between the performance on the pre-test question and the assign group was not significant, suggesting that students in both groups performed similarly on the pre-test questions (Table 1). However, the relation between performance on the post-test question and assigned group was significant, suggesting that case-base group students performed better on the post-test question when compare with non-case-based group.

Table 1. Addressing the answer of multiple choice question

\begin{tabular}{|c|c|c|c|c|}
\hline \multirow{2}{*}{ Respondent } & \multicolumn{2}{|c|}{ Incorrect answer (\%) } & \multicolumn{2}{c|}{ Correct answer (\%) } \\
\cline { 2 - 5 } & Pre- & Post- & Pre- & Post- \\
\hline $\begin{array}{c}\text { Case-based group } \\
\mathrm{n}=37\end{array}$ & $35.1(13)$ & $13.5(5)$ & $64.9(24)$ & $86.5(32)$ \\
\hline $\begin{array}{c}\text { Non-case-based } \\
\text { group n=39 }\end{array}$ & $35.8(14)$ & $17.9(7)$ & $64.2(25)$ & $82.1(32)$ \\
\hline
\end{tabular}

\section{Students' attitude}

An evaluation of students' attitude using an attitudinal questionnaire was used to gain information on the ability of the case study to promote attitude change.

To determine which students initially held the operating system, students' response on evaluation of students' attitude were tabulated and the chi-square test was used to determine if a relationship existed between students' responses and the assigned group (Table 2).

The pre-test attitude on the learning experience scale in each group was negative $(\mathrm{p}<0.001$, Wilcoxon signed-rank test). The same result was shown on the knowledge scale. Pre-test on collaboration scale was not significantly different from zero (undecided) for non-case-based group, and negative for case-based group. Analysis of the post-test result showed a positive attitude of the knowledge scale for each group. However, for the learning experience and collaboration scale was positive for case-based group. The 
post-test attitude on the collaboration scale showed no change for non-case-based group, but different result was shown that learning experience scale with a median of zero gave a significant result. There was a significant positive attitude on the knowledge scale for post-tests.

Most of the zero non-case-based group comments were related to the experience in post-test, as is illustrated in the quote "the class was boring, no case study, and only writing" for learning experience. However, on collaboration, the majority of students said that the class has a little discussion of case study. This situation made the students become passive and not interested in discussion.

On the post-test attitude responses, a greater proportion of students in case-based group reported, usage of higherorder thinking skills such as critical thinking (81\%) and problem solving skills $(70.3 \%)$, and the ability to apply concepts learned from class $(81 \%)$ when compared with the non-case-based group (Table 2).

Table 2. Analysis of questionnaire

\begin{tabular}{|c|c|c|c|}
\hline \multirow[b]{2}{*}{ Category } & \multirow[b]{2}{*}{ Question } & \multicolumn{2}{|c|}{ Reponses (\%) } \\
\hline & & $\begin{array}{l}\text { Case- } \\
\text { based } \\
(n=37)\end{array}$ & $\begin{array}{l}\text { Non- } \\
\text { case- } \\
\text { based } \\
(\mathrm{n}=39)\end{array}$ \\
\hline $\begin{array}{l}\text { Learning } \\
\text { experience }\end{array}$ & $\begin{array}{l}\text { Critical thinking } \\
\text { 1.I now know of some } \\
\text { approaches that might work } \\
\text { better to solve the operating } \\
\text { system problem. } \\
\text { 2. I can absorb information much } \\
\text { easier and enjoyable. } \\
\text { Problem solving } \\
\text { 3. Case studies help me figure out } \\
\text { what the problem. } \\
\text { 4. These activities help me to } \\
\text { increase my skill. }\end{array}$ & $\begin{array}{l}81(30) \\
75.7(28) \\
70.3(26) \\
91.9(34)\end{array}$ & $\begin{array}{c}25.6(10) \\
12.8(5)\end{array}$ \\
\hline $\begin{array}{l}\text { Knowledge } \\
\text { category }\end{array}$ & $\begin{array}{l}\text { Application of concepts } \\
\text { 5. This activity made me apply in } \\
\text { case study what I learn in the } \\
\text { class. } \\
\text { 6. I can make decision effectively. } \\
\text { Connected with real situation } \\
\text { 7. There was something that I } \\
\text { could relate to real life. }\end{array}$ & $\begin{array}{c}81(30) \\
32.4(12) \\
56.7(21)\end{array}$ & $\begin{array}{l}15.4(6) \\
12.8(5) \\
30.7(12)\end{array}$ \\
\hline $\begin{array}{l}\text { Collaborati } \\
\text { on skills }\end{array}$ & $\begin{array}{l}\text { Promoted collaboration } \\
\text { 8. I was able to get into groups } \\
\text { and learn from each other. } \\
\text { 9. Collaboration of task and } \\
\text { friend is taking too much time } \\
\text { Hands-on activity } \\
\text { 10. This activity gave a more a } \\
\text { hands on approach }\end{array}$ & $\begin{array}{l}100(37) \\
45.9(17)\end{array}$ & $\begin{array}{l}94.9(37) \\
48.7(19)\end{array}$ \\
\hline
\end{tabular}

\section{Conclusion}

Research in vocational education investigated how students optimally learn the operating system and evaluated the most effective learning environments to achieve learning objectives. The study described here shows some impact of the case-based learning in influencing a change in knowledge and attitudes of students. This current study begins to address how case-based learning can make an effect on students' achievement.
The study has made it possible to evaluate students' knowledge and attitudes. Knowledge and attitudes have been assessed both before and after the treatment. A number of significant differences have been identified between casebased groups and non-case-based group. The data showed that this study leads to increase learning gain when compared with the traditional model of learning. The evaluation, analysis of knowledge indicated that learning gain results from this study fell within a significant learning gain as established by comparing active learning using casebased learning versus traditional pedagogies.

Similar to the results on students' knowledge, evaluation of attitudes indicated that case-based learning provide opportunities for developing knowledge and collaboration, increasing learning experience, and achieving problem solving and skill.

\section{Acknowledgments}

The authors would like to acknowledge their colleagues at SMK Negeri 2 Cimahi, Indonesia, who worked together to create an innovative engineering program with a focus on case-based learning. They would also like to thank the Universitas Pendidikan Indonesia, who gives the research grant.

\section{References}

[1] N. Hosseinzadeh and M. R. Hesamzadeh, "Application of project-based learning to the teaching of electrical power systems engineering," IEEE Transactions on Education, vol. 55, no. 4, pp. 495-501, 2012.

[2] C. Herreid, "Case studies in science - A novel method of science education," J. Coll. Sci. Teach, pp. 221-229, 1994.

[3] U. B. Kjaerulff, C. A. F. Rosenstand, J. Stage and M. Vetner, "Cassebased learning (CBL): A new pedagogical approach to multidiciplinary studies," in 36th SEFI Annual Conference - Quality Assessment, Employability and Innovation.ed., Aalborg, Denmark, 2008.

[4] G. Marcus, R. Taylor and R. A. Ellis, "Implications for the design of online case-based learning activities based on the student blended learning experience," in Proceedings of the 21st ASCILITE Conference, Sydney, Australia, 2004.

[5] R. Hake, "Interactive-engagement vs. traditional methods: A sixthousand-student survey of mechanics test data for introductory physics courses," Am. J. Phys, vol. 66, pp. 64-74, 1998.

[6] B. J. Rybarczzyk, A. T. Baines, M. McVey, J. T. Thomson and H. Wilkins, "A case-based approach increases students learning outcomes and comprehension of cellular respiration concepts," Biochemistry and Molecular Biology Education, vol. 35, no. 3, pp. 181-186, 2007. 